\title{
Estimation of Solar Hot Water System Operation for a Residential Building
}

\author{
Olena Savchenko *, Zenon Savchenko \\ Lviv Polytechnic National University, 12, S. Bandery Str., Lviv, 79013, Ukraine
}

Received: November 27, 2020. Revised: December 02, 2020. Accepted: December 28, 2020.

(C) 2021 Authors. Published by Lviv Polytechnic National University.

\begin{abstract}
Solar hot water supply systems can provide a significant part of the thermal energy needed in the residential sector. The use of solar hot water supply systems can reduce the consumption of traditional energy sources and, consequently, reduce greenhouse gas emissions. The aim of this article is to assess the operation of the solar heating system operation to provide the needs of the hot water supply system of a residential building with thermal energy. The efficiency of a flat solar collector operating in a single-circuit thermosyphon system of solar heating of a residential building in Lviv has been established. The solar fraction of the hot water supply system of a residential building is determined depending on the volume of hot water consumed, in particular 50, 60, 70, 80, 90, 100 1/day. It is established that the lower the need for hot water, the greater the solar fraction of the solar hot water supply system. Thus, the average annual solar fraction of the solar hot water supply system with a daily consumption of $501 /$ day is 0.77 , and with a daily consumption of $100 \mathrm{l} / \mathrm{day}$ the solar fraction is 0.39 . The average value of the solar fraction for the solar hot water supply systems of the studied house is 0.55 .
\end{abstract}

Keywords: solar water heating system; hot water supply system; solar collector; solar radiation; solar fraction.

\section{Introduction}

Heat water supply systems are designed to provide hot water for sanitary, hygienic and technological needs of consumers in residential, public and industrial buildings. Depending on the type of heat source, heat water supply systems are district and decentralized. In district heating systems, several heat consumers are connected to one heat source. Thus generation of thermal energy occurs in boiler houses or Combined Heat and Power (CHP), and supply of the heat carrier from a heat source to consumers is carried out by a network of pipelines [1,2]. Boiler houses and CHPs can use as fuel both traditional and alternative energy sources. To reduce the negative impact on the environment in the production of thermal energy in boilers and CHPs, it is advisable to use renewable energy sources, including residues of forestry and woodworking industry, agricultural waste, household waste [3, 4]. In Ukraine, due to the significant cost of thermal energy and the lack of possibility to regulate the quantity of coolant by consumers, the population is massively abandoning district heating. A significant number of people in small towns and villages of Ukraine are switching to decentralized heating systems, in which only one consumer is connected to one heat source, which allows for qualitative and quantitative regulation of the coolant as needed directly by the consumer. In Ukraine, in decentralized heat supply systems, electric and gas heat generators are most often used as a heat source.

To reduce dependence on traditional energy sources in the preparation of hot water in decentralized heating systems, it is advisable to use solar energy. For this purpose, active solar water heating systems are being developed, in which solar energy is converted into thermal energy in solar collectors [5, 6]. Solar heat supply systems can provide hot water to a hot water supply, heating or cooling system. Depending on the period of use of the solar heating system there are seasonal and year-round. Seasonal (thermosyphon) solar water heating systems are used at

\footnotetext{
* Corresponding author. Email address: o.savchenko@i.ua
}

This paper should be cited as: O. Savchenko, Z. Savchenko. Estimation of solar water heating system operation for a residential building. Energy Engineering and Control Systems, 2021, Vol. 7, No. 1, pp. 1 - 6 . https://doi.org/10.23939/jeecs2021.01.001 
positive outdoor temperatures, they are compact and easy to install. Year-round solar heating systems are used regardless of the temperature of the outside air, so they need an additional heat source, circulating pump, antifreeze, which increases their cost and complicates the design of the system.

In small households to meet the needs of hot water domestic water system, it is advisable to use thermosyphon solar heating systems, which in the warm and transitional periods of the year will save traditional energy resources for water heating.

\section{Aim of work}

The aim of the work is to assess the operation of the solar heat supply system to provide the needs of the hot water supply system of a single-family house in Lviv thermal energy.

\section{Analysis of recent research}

To assess the operation of the solar heat supply system, its efficiency is determined. The efficiency of the solar heat supply system is characterized by two indicators, in particular the efficiency of the solar collector and the solar fraction.

The efficiency of a flat solar collector is determined by the formula:

$$
\eta=\frac{Q_{\text {useful }}}{Q_{\text {inc }}},
$$

where $Q_{\text {useful }}$ is useful thermal energy provided by the solar collector; $Q_{i n c}$ is the amount of solar radiation that receives to the solar collector.

The useful thermal energy provided by the solar collector can be determined by a Hottel-Whillier-Bliss equation $[7,8]$ :

$$
Q_{u s e f u l}=F_{R} \cdot A \cdot\left[(\tau \alpha) \cdot I_{t}-U_{L} \cdot\left(T_{h}-T_{a}\right)\right]
$$

where $F_{R}$ is heat removal factor of the solar collector; $A$ is the solar collector area, $\mathrm{m}^{2} ; I_{t}$ is intensity of solar radiation, $\mathrm{W} / \mathrm{m}^{2} ; \tau, \alpha$ are coefficients of transmission and absorption of solar energy by the collector; $T_{a}$ is the ambient monthly outside air temperature of the solar collector installation place, $\mathrm{K} ; U_{L}$ is heat loss coefficient of the solar collector, $\mathrm{W} /\left(\mathrm{m}^{2} \cdot \mathrm{K}\right)$.

The amount of solar radiation that receives to the solar collector is defined as:

$$
Q_{i n c}=I_{t} \cdot A
$$

Then, the efficiency of a flat solar collector can be written as [7]:

$$
\eta=(\tau \alpha)-\frac{U_{L} \cdot\left(T_{h}-T_{a}\right)}{I_{t}} .
$$

Solar fraction is the amount of solar energy in the total load on hot water supply, which is determined by the formula:

$$
f=\frac{Q_{\text {solar }}}{Q_{\text {load }}},
$$

where $Q_{\text {solar }}$ is the amount of thermal energy for the needs of the hot water supply system, which can be provided by solar energy, namely $Q_{\text {solar }}=Q_{\text {useful }} ; Q_{\text {load }}$ is general needs for thermal energy by the hot water supply system. 
General needs for thermal energy can be written in the form of a formula:

$$
Q_{\text {load }}=Q_{\text {solar }}+Q_{a d}
$$

where $Q_{a d}$ is the amount of thermal energy for the needs of the hot water supply system, which is produced using additional energy sources.

The monthly amount of thermal energy required for hot water supply system is determined by the formula [7]:

$$
Q_{\text {load }}^{m}=V_{w} \cdot \rho_{w} \cdot N_{d} \cdot c_{p w} \cdot\left(T_{h}-T_{c}\right)
$$

where $V_{w}$ is the total volume of hot water used by the hot water supply system of the house per day, L/day; $\rho_{w}$ is water density, $\mathrm{kg} / \mathrm{L} ; N_{d}$ is number of days in a month, days; $c_{p w}$ is specific heat capacity of water, $\mathrm{kW} \cdot \mathrm{h} /(\mathrm{kg} \cdot \mathrm{K}) ; T_{h}$ is hot water temperature in the hot water supply system, $\mathrm{K} ; T_{c}$ is the inlet temperature of cold water, $\mathrm{K}$.

\section{Research results}

Thermosyphon systems of solar heat supply consist of a stationary solar collector and, connected to it, a tankaccumulator, and the heat carrier is water of a contour of hot water supply. Thermosyphon systems can be open, operating in pressureless mode and closed, in which water is supplied under pressure. In open thermosyphon systems, water enters the system and flows out of it by gravity, so all solar system equipment must be located above the faucet, and the hot water pressure in the system will depend on the height difference between the collector and the faucet. Therefore, in thermosyphon systems of hot water supply with natural circulation, the lower point of the accumulator tank should be located above the upper point of the collector and be at a distance of not more than 3-4 $\mathrm{m}$ from the collector.

To evaluate the operation of the solar heating system, a single-circuit thermosyphon solar heating system was selected to meet the hot water needs of the hot water supply system.

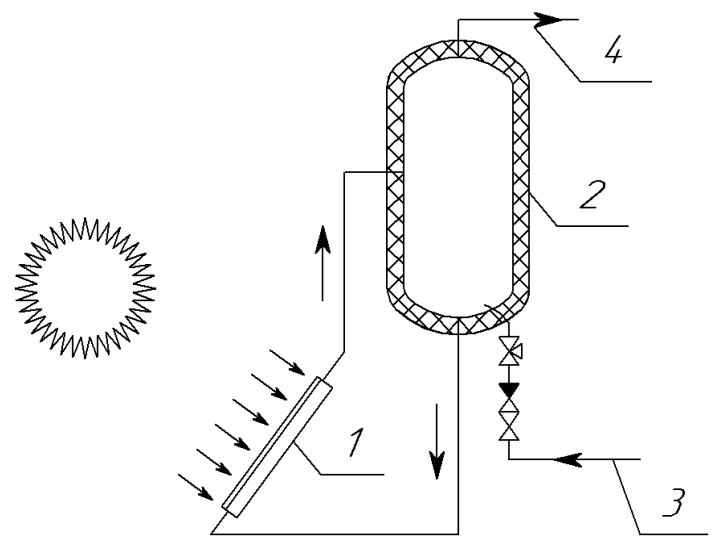

Fig.1. Schematic diagram of a single-circuit thermosyphon solar hot water system.

1 - solar collector, 2 - storage tank, 3 - cold water from water supply system, 4 - heated water outlet

The single-circuit thermosyphon solar hot water system works as follows. Solar radiation passes through the transparent coating of the collector and heats its absorption panel, and accordingly, the water in its channels. When heated, the density of water decreases, which leads to the movement of the heated coolant to the upper point of the collector, and then through the pipeline to the storage tank. In the storage tank, due to natural circulation, the heated water also moves to the upper point, and the cold water is located in the lower part of the tank. Cold water from the lower part of the tank enters the lower part of the collector through a pipeline. Thus, in the presence of sufficient solar radiation, a constant circulation is established in the collector circuit, the speed and intensity of which depend on the flux densities of solar radiation. Gradually, during daylight, the water in the tank is completely heated. The selection 
of water in this scheme should be carried out from the top of the tank, by supplying cold water to the tank from below under pressure, which displaces the heated water from the tank.

The average daily amount of solar energy during the month that enters the collector surface depends on the construction site and the angle of the collector [9]. The average monthly intensity of solar radiation coming to the solar collector located in Lviv city, which is inclined to the horizon by $45^{\circ}$, is shown in Fig.2.

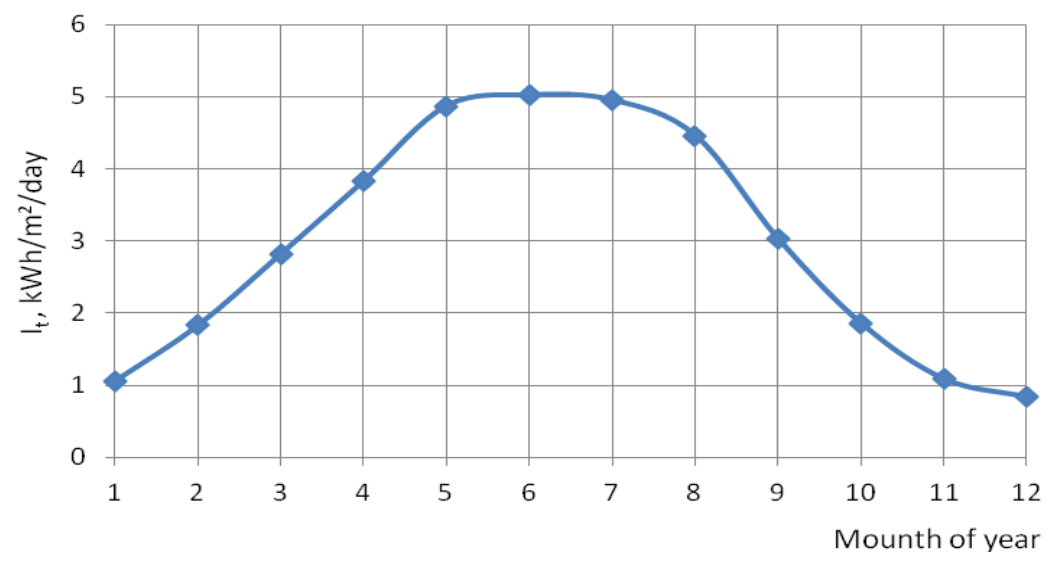

Fig. 2. Monthly variation of global radiation on the surface of the solar collector tilted by an angle of $45^{\circ}$ [9]

The auroTHERM classic VFK 135/2 D flat solar collector [10] with the area $A=2.35 \mathrm{~m}^{2}$ and such technical characteristics glass transparency coefficient $\tau=0.91$, adsorber absorption coefficient $\alpha=0.95$, solar collector heat loss coefficient $U_{L}=3.93 \mathrm{~W} / \mathrm{m}^{2} / \mathrm{K}$ is accepted for perception of solar radiation. The heat transfer coefficient of the solar collector will be accepted $F_{R}=0.69$ [7].

The solar collector receives solar radiation for several hours a day, the amount of which depends on the season, clouds and the construction site of the installation. The average daily number of hours of sunshine in the months of the year in Lviv is given in [11] and is shown in Fig.3.

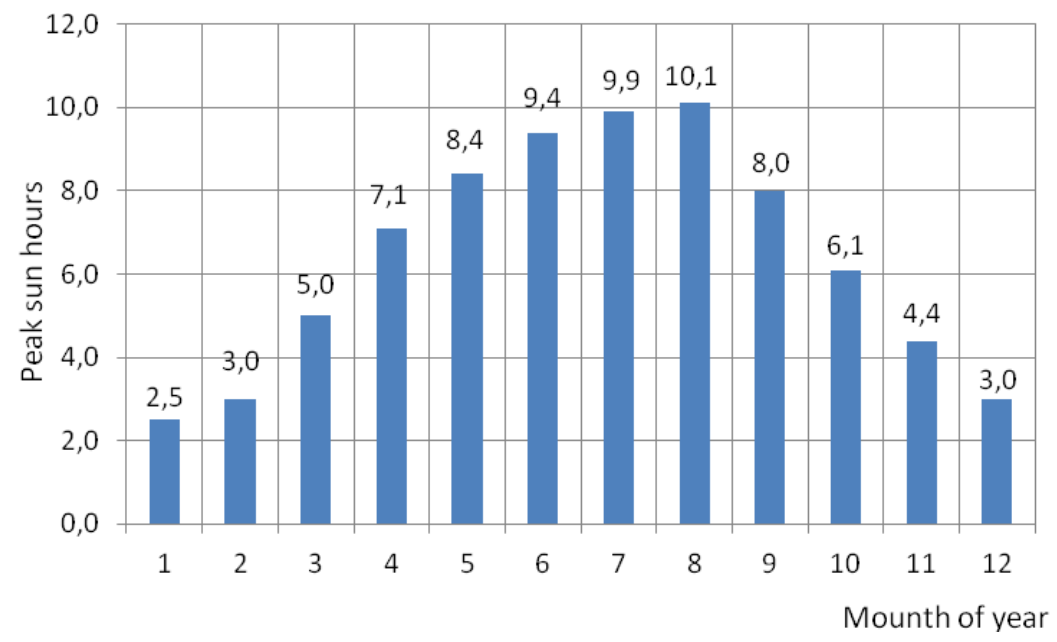

Fig.3. Average daily number of sunny hours by months of the year in Lviv [11]

The hot water supply system is designed for a single-family house located in Lviv, where 4 people live. The temperature of tap water is $5{ }^{\circ} \mathrm{C}$ in the cold period of the year, in the warm period of the year it is $15{ }^{\circ} \mathrm{C}$. The temperature of hot water after the solar collector is $50{ }^{\circ} \mathrm{C}$. The solar fraction was determined for hot water supply systems, in which the daily consumption of hot water was 50,60,70,80, 90 and $1001 /$ day, respectively. The results of the calculation of the solar fraction for hot water supply systems are presented in Fig.4. 


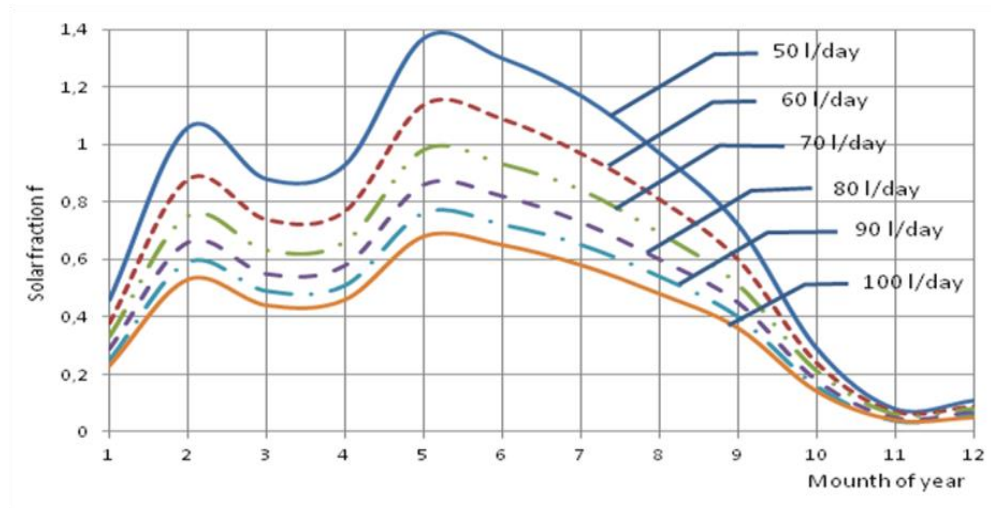

Fig.4. Solar fraction of hot water supply system of a single-family house in Lviv depending on the volume of hot water consumed

As can be seen from Fig. 4, the solar fraction of the hot water supply system decreases with increasing volume of hot water consumed. Thus, the solar hot water supply system with a daily consumption of $501 /$ day can cover the entire load of hot water in the system for 4 months, 5 months a year the solar fraction of the system is in the range of 0.46-0.97 and three months the solar fraction is less than 0.3 . The average annual solar fraction for a hot water supply system with a daily consumption of $50 \mathrm{l} /$ day is 0.77 . The lowest value of the solar fraction for the hot water supply system of these options corresponds to the system with a daily hot water consumption of 100 1/day. Solar collector can provide this system with thermal energy by no more than $68 \%$, namely the maximum solar fraction for a hot water supply system with a daily hot water consumption of $100 \mathrm{l} / \mathrm{day}$ is 0.68 . The average annual solar fraction for such a system is 0.39 . The highest values of the solar fraction for all systems are observed in May, June and July. The average value of the solar fraction for hot water supply systems of a single-family house built in Lviv and hot water consumption of 50,60, 70, 80, 90 and 100 1/day is 0.55 . Thus, the solar hot water supply system allows obtain thermal energy for heating hot water, and accordingly save traditional types of energy resources by an average of $45 \%$.

The efficiency of a flat solar collector is determined from its technical characteristics and climatological parameters for Lviv. The value of the efficiency of a flat solar collector when working in the hot water supply system of a single-family house built in Lviv for different months of the year is shown in Fig. 5.

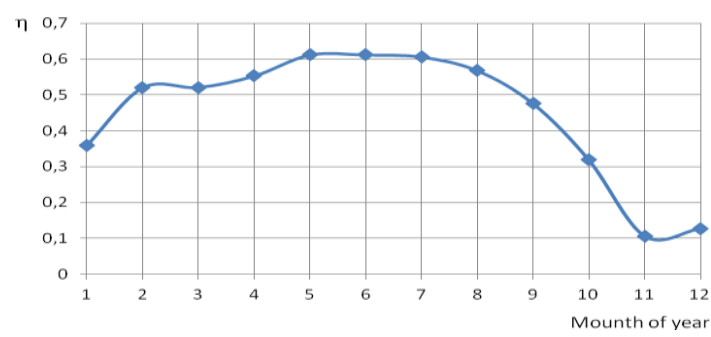

Fig.5. Efficiency of a flat solar collector of the solar hot water supply system of a single-family house built in Lviv

As can be seen from Fig. 5, the efficiency of the solar collector depends on the month of the year, in particular on the average monthly outdoor temperature and varies from 0.11 to 0.61 , which is less than the standard efficiency of the received collector, namely 0.782 .

\section{Conclusion}

This article establishes the efficiency of the solar hot water supply system of a single-family house built in Lviv. The efficiency of the solar collector is determined, which depends on the outside air temperature and varies during the year in the range of 0.11-0.61. The solar fraction has been determined for the solar hot water supply system. It depends on the consumption of hot water, climatological parameters of the construction place and the characteristics of the solar collector. The largest solar share was observed for the months of May, June, July. Thus, the solar hot water supply system with a daily consumption of 501 / day can cover the entire load of hot water in the system for 4 months, 5 months a year the solar fraction of the system is in the range of 0.46-0.97 and three months the solar fraction is less than 0.3 . The average annual solar fraction for a hot water supply system with a daily consumption of 
$50 \mathrm{l} /$ day is 0.77 . The lowest value of the solar fraction for the hot water supply system of these options corresponds to the system with a daily hot water consumption of $100 \mathrm{l} / \mathrm{day}$. Solar collector can provide this system with thermal energy by no more than $68 \%$, the maximum solar fraction for a hot water supply system with a daily hot water consumption of $100 \mathrm{l} / \mathrm{day}$ is 0.68 . The average annual solar fraction for such a system is 0.39 . The average value of the solar share for hot water supply systems of a single-family house built in Lviv and hot water consumption of 50, $60,70,80,90$ and $100 \mathrm{l} / \mathrm{day}$ is 0.55 . In the future, it is advisable to determine the economic performance of the solar hot water system, in particular the capital costs of the system and its payback period.

\title{
References
}

[1] Wojdyga. K., Chorzelski M. (2017) Chances for Polish district heating systems. Energy Procedia, 116, 106-118.

[2] Millar M.-A., Burnside N. M., Yu Z. (2019) District heating challenges for the UK. Energies, 12(2), 310. https://doi.org/10.3390/en12020310

[3] Mendoza R.C., Hernandez J. M. R., Gomes E. V., Alonso J. F. S. J., Martinez F. J. R. (2019) Analysis of the methodology to obtain several key indicators performance (KIP), by energy Retrofitting of the actual building to the district heating fuelled by biomass focusing on nZEB goal: case of study. Energies, 12(1), 93. https://doi.org/10.3390/en12010093

[4] Savchenko O., Zhelykh V., Yurkevych Y., Kozak K., Bahmet S. (2018) Alternative energy source for heating system of woodworking enterprise. Energy engineering and control systems, 4 (1), 27 - 30. https://doi.org/10.23939/jeecs2018.01.027

[5] Nshimyumuremyi E., Junqi W. (2019) Thermal efficiency and cost analysis of solar water heater made in Rwanda. Energy exploration \& exploitation, 37(3) 1147-1161. https://doi.org/10.1177/0144598718815240

[6] Tadvi Sachin Vinubhai, Jain Vishal R, Dr. Keyur Thakkar, A Review: Solar Water Heating Systems file://C:/Users/Osa/Downloads/SachinKeyurSolarReviewpaper.pdf

[7] Serban A., Barbuta-Misu N., Ciucescu N., Paraschiv S., Paraschiv S. (2016) Economic and environmental analysis of investing in solar water heating systems. Sustainability, 8(12), 1286; https://doi.org/10.3390/su8121286

[8] Struckmann F. (2008) Analysis of a Flat-plate Solar Collector. MVK160 Heat and Mass Transport, 4 p. http://www.lth.se/fileadmin/ht/Kurser/MVK160/Project_08/Fabio.pdf

[9] Solar Electricity Handbook. (2019) http://www.solarelectricityhandbook.com/solar-irradiance.html

[10] Vaillant, auroTHERM classic VFK 135/2 D https://www.vaillant.ua/dlia-klientiv/produktsia/aurotherm-classic-vfk-135-2-d-vd13056.html\#specification (in Ukrainian)

[11] Weather in Lviv: July. https://tur-pogoda.com.ua/ukraine/lvov/july. (in Ukrainian)

\section{Оцінка роботи сонячної системи гарячого водопостачання житлового будинку}

\author{
Олена Савченко, Зенон Савченко \\ Національний університет «Львівська політехніка», вул. С. Бандери, 12, Львів, 79013, Украйна
}

\section{Анотація}

Системи сонячного гарячого водопостачання можуть забезпечити значну частину теплової енергії, необхідної в житловому секторі. Використання систем сонячного гарячого водопостачання дозволяють зменшити споживання традиційних видів енергії, а, відповідно, зменшити викиди парникових газів. Мета даної статті полягає у оцінці роботи системи сонячного теплопостачання для забезпечення потреб системи гарячого водопостачання житлового будинку тепловою енергією. Встановлено ефективність плоского сонячного колектора, який працюе у одноконтурній термосифонній системі сонячного теплопостачання житлового будинку у м. Львів. Визначено сонячну частку системи гарячого водопостачання житлового будинку залежно від об’єму гарячої води, яка споживається, зокрема 50, 60, 70, 80, 90, 100 л/добу. Встановлено, чим менша потреба у гарячій воді, тим більша сонячна частка системи сонячного гарячого водопостачання. Так, середньорічна сонячна частка система сонячного гарячого водопостачання зі щоденним споживанням 50 л/добу становить 0,77 , при щоденному споживанні 100 л/добу - сонячна частка дорівнює 0,39. Середнє значення сонячної частки для систем сонячного гарячого водопостачання досліджуваного будинку становить 0,55 .

Ключові слова: система сонячного теплопостачання; система гарячого водопостачання; сонячний колектор; сонячне випромінювання; сонячна частка. 